\title{
THE NORMAL RANGE AND THE DECISION INTERVAL
}

\section{ZAKRES NORMY I PRZEDZIAŁ DECYZYJNY}

\author{
ul. Konopnickiej 53, 71-132 Szczecin
}

\begin{abstract}
Streszczenie
W pracy przedstawiona została koncepcja przedziału decyzyjnego zastępującego zakres normy w podejmowaniu decyzji medycznych w warunkach współczesnej medycyny opartej na dowodach i procedurach. Omówiono sposób wyznaczania przedziału decyzyjnego i niektóre jego właściwości.
\end{abstract}

H a s $\nmid$ a: pomiar - zakres normy - zdrowie - decyzja diagnostyczna - przedział decyzyjny - medycyna zapobiegawcza.

\section{Summary}

The concept of the decision interval which replaces the normal range in medical decision-making in the contemporary setting of evidence- and procedure-based medicine is presented. The definition and some properties of the decision interval are discussed.

K e y w o r d s: measurement - normal range - health diagnostic decision - decision interval preventive medicine.

\section{$*$}

Ever since man learned to count and to measure he soon noticed that his own body could be measured as well. The first two obvious quantities measurable were height and weight. Repeated measurements in a population disclosed that the height and weight of most people lies within a certain range of values; whatever within this range was deemed typical or normal. So entered the normal range which was next logically associated with health and disease [1]. When heights or weights (and many other quantitative variables of the body) are plotted against their incidence, a distribution is revealed that clusters around a certain value and approaches zero incidence at either extreme. Extreme values raise suspicion as to their association with an abnormality (disease) and so it became accepted that the normal range should include $95 \%$ of values $(2.5 \%$ on either extreme of the range are excluded). This proposal obviates one doubt but raises another: how should this $5 \%$ be treated? Obviously, all measurements for the normal range are done exclusively in healthy individuals. The answer is of importance to medicine in general and to preventive medicine in particular. Exclusion may produce an error in the diagnostic decision (health or disease). We must rather ask whether the normal range is the best beacon to guide these decisions.

Contemporary medicine is evidence- and procedure-based. Is it not time to replace the normal range by an approach that departs from the traditional health/disease classification and matches measured values (evidence) with procedures (action)? The replacement has been around for years but has not been named. Let us name it the "decision interval" (DI). We can now move to formulate the basic equation of DI.

$$
\mathrm{DI}_{\mathrm{N}}=[\mathrm{x}, \mathrm{y}]
$$

where $\mathrm{N}$ is an integer (usually from -3 to +3 ), $\mathrm{x}$ is the lower and $\mathrm{y}$ is the upper endpoint. We thus obtain a set of DI that covers the whole range of values found in physiology and pathology, with each DI corresponding to action (or no action) to be taken for values within this DI. The number of DI over the whole range can be increased or decreased, as needed. Thus, DI is not defined in a fixed 
$\mathrm{T}$ a b 1 e 1 . An example of decision intervals: fasting glycemia

\begin{tabular}{ll}
$\begin{array}{c}\text { Decision } \\
\text { interval }\end{array}$ & \multicolumn{1}{c}{ Action } \\
\hline $\mathrm{DI}_{-2}=\left(\leq \mathrm{x}_{-2}\right]$ & $\begin{array}{l}\text { Life-threatening hypoglycemia, immediate } \\
\text { administration of glucose }\end{array}$ \\
\hline $\mathrm{DI}_{-1}=\left[\mathrm{x}_{-1}, \mathrm{y}_{-1}\right]$ & Hypoglycemia, search for cause \\
\hline $\mathrm{DI}_{0}=\left[\mathrm{x}_{0}, \mathrm{y}_{0}\right]$ & No action \\
\hline $\mathrm{DI}_{1}=\left[\mathrm{x}_{1}, \mathrm{y}_{1}\right]$ & Dietary modification \\
\hline $\mathrm{DI}_{2}=\left[\mathrm{x}_{2}, \mathrm{y}_{2}\right]$ & Oral glucose tolerance test \\
\hline $\mathrm{DI}_{3}=\left[\mathrm{x}_{3}, \mathrm{y}_{3}\right]$ & Diabetes mellitus, search for cause \\
\hline $\mathrm{DI}_{4}=\left[\geq \mathrm{x}_{4}\right)$ & $\begin{array}{l}\text { Life-threatening hyperglycemia, } \\
\text { administration of insulin }\end{array}$ \\
\hline
\end{tabular}

DI - decision interval; $\mathrm{x}$ - lower endpoint; $\mathrm{y}$ - upper endpoint.

manner. Rather, it depends on the actual medical knowledge, choice of procedures, measurement method and instrument, population studied, even the economic situation of that population.
Let us assign 0 to $\mathrm{N}$ and regard $\mathrm{DI}_{0}$ as the interval that is essentially physiologic ("normal") and requiring no further action. For a parameter like e.g. fasting glycemia, $\mathrm{DI}_{0}$ will include all values which require no elucidation of glucose turnover status. Negative and positive $\mathrm{N}$ will be assigned to DI with values smaller or greater than those in $\mathrm{DI}_{0}$, respectively. The result of this process is presented in Table 1 .

The first and last interval will have one endpoint value. The exact values for $\mathrm{x}$ and $\mathrm{y}$ remain to be determined as discussed above, always with regard to categorization accuracy. For preventive medicine which relies heavily on screening tests, decision intervals should prove particularly useful.

\section{Reference}

1. Jhang J.S., Sireci A.N., Kratz A.: Postanalysis: medical decision making. In: Henry's Clinical Diagnosis and Management by Laboratory Methods. $22^{\text {nd }}$ Edition. Eds: R.A. McPherson, M.R. Pincus. Elsevier Saunders, Philadelphia 2011, 80-108. 